\title{
How Can Scientific Approach Enhancing Student's Curiosity and Learning Outcomes in Science Learning?
}

\author{
Edysyah Putra ${ }^{1, *}$ Agung Wijaya Subiantoro ${ }^{2,}$ Suhartini ${ }^{2}$ \\ ${ }^{I}$ Master of Biology education, Faculty of Mathematics and Natural Sciences, Universitas Negeri Yogyakarta, \\ Indonesia \\ ${ }^{2}$ Department of Biology Education, Faculty of Mathematics and Natural Sciences, Universitas Negeri \\ Yogyakarta, Indonesia \\ Corresponding author: Edysyahputra.2019@student.uny.ac.id
}

\begin{abstract}
The purpose of this research is to determine the application of the scientific approach is assumed to increase curiosity and student learning outcomes. implementation carried out in the study using the classroom action research method (CAR). This research begins with planning actions, implementing actions, observing and evaluating the processes and results of actions. While the work procedure in classroom action research consists of four components, namely planning, implementing, observing, and reflecting, and so on until the expected improvement or improvement is achieved (success criteria). The data collection design used in this study was a test sheet to obtain data on student learning outcomes, interviews to obtain initial information about student abilities, and observations to see an increase in student curiosity. To achieve the research objectives used data analysis design, namely data reduction, data presentation (data display), and data validity. The cycle begins with pre-action showing the percentage: (a) curiosity $14.3 \%$ (4 students) and (b) $35.7 \%$ learning outcomes (10 students) and cycle I shows: (a) attitude 39.3\% (11 students) and (b) learning outcomes of 50\% (14 students). Cycle II shows: (a) curiosity 75\% (21 students) and (b) $82.1 \%$ (28 students) learning outcomes. From pre-action to cycle I and to cycle II, curiosity and student learning outcomes have increased. The results showed that the scientific approach could increase students' curiosity and learning outcomes.
\end{abstract}

Keywords: Scientific approach, Students curiosity, Student's learning outcome

\section{INTRODUCTION}

Quality human resources will play an important and strategic role in building the nation, this can be achieved through education. The function of education is in accordance with the definition of national education as regulated in Law Number 20 of 2003, namely Education is a conscious and planned way to shape learning conditions and the learning process so that students actively develop their abilities. spiritualreligious strength, self-control, expertise, capabilities, good morals, and skills needed by them, society, nation and state. Thus education must be formed to produce human beings who are useful, able to compete, have noble character, and the ability to compete [1].

21 st century education prepares students to possess 7 skills including 1) critical thinking and solving every problem, 2) leadership and teamwork, 3) social adaptability, 4) entrepreneurial spirit and initiative in every situation, 5) good effective communication orally or in writing, 6) able to access, analyze and process information and 7) have curiosity and imagination [2]. Education is developed and formulated based on the needs of 21 st century human resources and the needs of the world of work so that the learning outcomes paradigm shifts to knowledge, skills, and attitudes [3]. If education has been adjusted to the needs as early as possible, students can be nurtured and honed so that they have skills that are ready to compete in the future, but on the other hand, if they are ignorant of the development of this century, it could be that the generation of students who will be born unproductive.

Curiosity is an object of research that has been the concern of researchers for several years because 
curiosity is one of the basic concepts in the development of science, philosophy, technology, and art. Curiosity is a sense that exists in every individual to encourage or motivate to have a desire to pay attention, reveal, and explore new things [4].

When observed the students of MTs.S ArRaudhatul Hasanah, the result showed that students' curiosity was low, this was evidenced by a lack of enthusiasm in paying attention to the teacher when explained the material, most of the students did not answer and did not ask the teacher. Van Hayus, Pramesthi, and Saputro [5] stated that the low curiosity of students can be seen from the lack of interest in asking, insecurity when submitting opinions in front of the class, and low awareness of preparing before learning, preparation can be done through reading material that has been given or not by the teacher.

Curiosity is one of the character values contained in character education, it is commonplace the importance of this attitude to be instilled in every student, this will also be a way that will make it easier for students to seek and find knowledge. The role of curiosity in students can provide a stimulus that will trigger students to keep trying to find out or learn knowledge from all available learning sources. With this curious attitude, students will become more active in solving and finding ways to solve any problems they find.

The higher the curiosity a student has, the higher the curiosity he has, of course, the positive impact is that students will continue to be motivated to find facts from a concept. However, there are still many who do not realize the importance of students' curiosity, in the learning process we always feel comfortable with approaches, methods, and strategies that are no longer relevant to the development of science. We always make students the object of receiving knowledge from the subject matter, still focus on explaining definitions without relating to the realities of life, of course, naturally, students' curiosity is low.

In the learning process the scientific approach is one of the learning approaches that can increase students' curiosity. The scientific approach is defined as a learning approach that has student-based activities. The learning process is designed with activities that can stimulate students to actively build knowledge through concepts, laws or principles. The stages in the scientific approach are through observation (observing, identifying and finding problems), compiling problem formulations, proposing hypotheses, collecting data using the following techniques; analyze data, draw conclusions, and communicate concepts, laws or principles found in the learning process. The purpose of the scientific approach is to construct and improve students' thinking skills, hone problem-solving skills systematically, develop character, put forward ideas, improve learning outcomes and make learning conditions more effective. [6]

The application of the scientific approach in the learning process includes the following activities: a) Observing (observation). The observation method usually presents objects in a real way so that it can make students more active, the learning process that is applied also emphasizes meaningful learning. b) Asking. When observing activities take place, the teacher will provide opportunities for students to ask some questions from what has been seen, listened to, read, and understood. Forms of questions can be factual or hypothetical questions. This activity can increase students' curiosity. c) Gathering Information. This activity is a follow-up to ask questions, carried out by gathering information from various sources. d) Associating/reasoning is an activity that processes some information which is obtained from various references and the results of experimental activities. e) Making Conclusions. After students process the information which is obtained, the next step is the students conclude the result of the observation process. f) Communicating. The climax of the scientific approach is to communicate each activity carried out by writing or telling [7]

\section{RESEARCH METHOD}

This study uses the classroom action research method (CAR). This research is a research conducted to observe student problems interactively and also to see the effect of implementing the actions given to research subjects in class. CAR is a research that raises problems that are actually experienced by students (occur in a concrete manner) and problems that are felt continuously by some students when teachers provide learning so that it can affect student motivation and learning outcomes [8]. So that researchers use CAR to find solutions to problems experienced by students, especially in curiosity and student learning outcomes in science learning which are categorized as low and have not reached the Minimum Completeness Criteria (KKM). The subjects in this study were 28 students of class VIII MTs.S Ar-Raudhatul Hasanah, Sibolga, Tapanuli Tengah.

The data was collected using instruments such as tests, interviews, and observation sheets. The collected data will be analyzed using the following methods: 1) The data is grouped, selected, focused and simplified based on the type of data that has been collected from the beginning to the end of the report preparation; 2) The data that have been selected and grouped are presented in the form of simple information in the form of students' curiosity and learning attitudes; 
3) data conclusions are then presented by describing each data found in the field, from these conclusions the collected data will be used as a test of the truth and meaning of the data.

Assessment of student learning outcomes is obtained from the cognitive test scores at the end of each cycle. This is to determine the increase in student learning outcomes seen from the completeness of student learning outcomes in each cycle. Students reveal (individually) in learning when the final score reaches $\geq 70$. In general, the success of learning outcomes is achieved and is successful when the completeness score reaches $80 \%$.

The data that has been collected will be analyzed by using comparative descriptive to show the comparison of the research results at the end of the learning cycle. The processes of data analysis consist of data reduction, data presentation, and conclusionmaking [9]. The procedures of research implementation consist of: (1) action planning; (2) executing the action; (3) observation; (4) reflection.

\section{RESULT AND DISCUSSION}

Based on the implementation of the actions in preaction, cycle I and cycle II, it was found that there was an improvement in students' attitude of curiosity and learning outcomes in the cognitive domain by using contextual learning with a scientific approach. The process of increasing the attitude of curiosity from the beginning of the pre-action can be seen in the table below.

Table 1. Results of observation of the pre-action curiosity attitude

\begin{tabular}{|c|c|c|c|l|}
\hline No & Score & Number of Students & Percentage & \multicolumn{1}{|c|}{ Completeness } \\
\hline 1 & 35 & 2 & 7.1 & Incomplete \\
\hline 2 & 40 & 3 & 10.7 & Incomplete \\
\hline 3 & 45 & 3 & 10.7 & Incomplete \\
\hline 4 & 50 & 5 & 18 & Incomplete \\
\hline 5 & 55 & 4 & 14.3 & Incomplete \\
\hline 6 & 60 & 5 & 18 & Incomplete \\
\hline 7 & 65 & 2 & 7.1 & Incomplete \\
\hline 8 & 70 & 2 & 7.1 & Completed \\
\hline 9 & 75 & 1 & 3.5 & Completed \\
\hline 10 & 80 & 1 & 3.5 & Completed \\
\hline & Average Amount $=$ & $\mathrm{N}=28$ & $100 \%$ & 4 (14.3\%) Completed and 24 \\
\hline
\end{tabular}

From the data above, at the beginning of the precycle action it was found that curiosity was still low, there were only 4 students who were able to achieve $14.3 \%$ completeness, then 24 students or $85.7 \%$ who had not completed. In this pre-cycle learning process, it has not used a scientific approach, so the results compiled are still low. At this stage it becomes the beginning of the researcher analysis to describe the state of curiosity that students have, of course at the end of the cycle the researcher reflects with the teacher, which is when the learning process is carried out we find that students are less interested in the learning given this is indicated by there were students some were asleep and some did not respond or sat still and did not interact, finally the researcher agreed to continue to cycle I. The scientific approach to this process is applied so that the results of changes in student curiosity can be known, this can be seen in the following table. 
Table 2. Observation results of curiosity attitude cycle I

\begin{tabular}{|c|c|c|c|l|}
\hline No & Score & $\begin{array}{l}\text { Number of } \\
\text { Students }\end{array}$ & Percentage & Completeness \\
\hline 1 & 35 & - & - & - \\
\hline 2 & 40 & - & 7.1 & - \\
\hline 3 & 45 & 2 & 10.7 & Incomplete \\
\hline 4 & 50 & 3 & 14.3 & Incomplete \\
\hline 5 & 55 & 4 & 14.3 & Incomplete \\
\hline 6 & 60 & 4 & 14.3 & Incomplete \\
\hline 7 & 65 & 4 & 14.3 & Completed \\
\hline 8 & 70 & 4 & 14,3 & Completed \\
\hline 9 & 75 & 3 & 10.7 & Completed \\
\hline 10 & 80 & $\mathrm{~N}=28$ & $100 \%$ & 11 (39.3\%) Completed and 17 (60.7\%) \\
\hline & Average Amount $=$ & & & Incomplete \\
\hline
\end{tabular}

The data obtained during the first cycle showed that the number of students who reached the completeness criteria was 11 students or $39.3 \%$ and 17 students or $60.7 \%$ did not complete, of the eleven students who managed to achieve the completeness score, including 4 students who did not complete. have been completed. complete which previously succeeded in achieving completeness scores in cycle I. The above shows that the application of the scientific approach to the learning process in cycle I show a change in student curiosity, slowly one by one student begins to dare to ask even though sometimes the questions given are not perfect. the first meeting in this cycle according to still trying to adapt to the scientific approach that was applied. researchers do not stop at this cycle alone, to look deeper into it change. The learning process is continued in the next cycle. The results of the improvements in cycle II can be seen in the following table.

Table 3. Observation results of curiosity attitude cycle II

\begin{tabular}{|c|c|c|c|l|}
\hline No & Score & Number of Students & Percentage & \multicolumn{1}{|c|}{ Completeness } \\
\hline 1 & 35 & - & - & - \\
\hline 2 & 40 & - & - & - \\
\hline 3 & 45 & - & - & - \\
\hline 4 & 50 & - & 7.1 & Incomplete \\
\hline 5 & 55 & 2 & 7.1 & Incomplete \\
\hline 6 & 60 & 2 & 10.7 & Incomplete \\
\hline 7 & 65 & 3 & 35.7 & Completed \\
\hline 8 & 70 & 10 & 28.6 & Completed \\
\hline 9 & 75 & 8 & 10.7 & Completed \\
\hline 10 & 80 & 3 & $100 \%$ & 21 (75\%) Completed 7 (25\%) \\
\hline & Average Amount $=$ & $\mathrm{N}=28$ & & Incomplete. \\
\hline
\end{tabular}

Based on the data above, a more significant increase was found, where the number of students who succeeded in achieving curiosity completeness scores was 21 students or $75 \%$ of the 28 students. These 
results indicate that the achievement of curiosity indicators has achieved maximum changes. The findings in this cycle which were revealed through reflection with the teacher, some students have experienced an increase, began to be confident in expressing opinions, respond to questions from teachers and fellow friends, provide explanations for each discussion, even be able to make a summary of each meeting, any obstacles in learning will be given alternative actions adapted to the situation and classroom circumstances. To see the increase in students' curiosity attitudes in each cycle, it is presented in Figure 1.

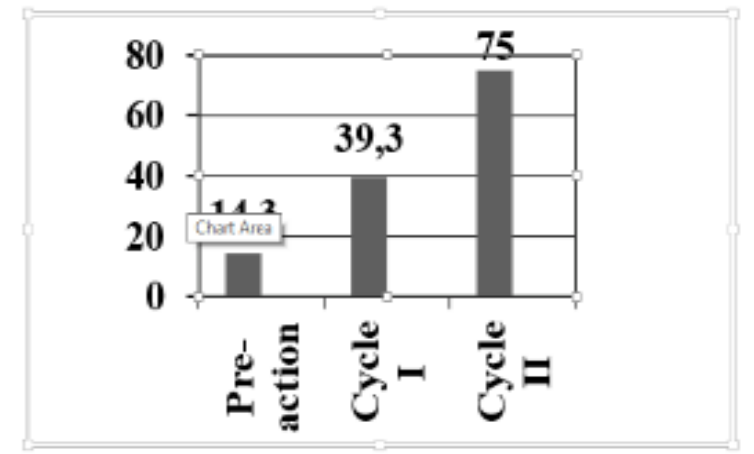

Figure 1 Observation result diagram of scientific attitude in pre cycle, cycle I and cycle II.

Based on the results of the observations that have been made during the learning process, it is obtained data that the application of the scientific approach to science learning can increase curiosity about the material which was taught. This is indicated by an improvement in students who actively ask questions during the learning process, besides that students also become more active in finding out and bringing other learning resources and the level of students' attention when the learning process becomes more attentive.
The number of confounding variables causes some students not to achieve maximum scores, such as differences in the character of each student, unhealthy physical conditions, lesson hours that are too close to recess, starvation conditions that result in lack of student concentration, so teachers must be more enthusiastic about creating an atmosphere. controlled learning. The treatment was carried out optimally, although it did not make all students have a good curiosity, the percentage data obtained proved that there were changes in students.

Students' learning outcomes in the cognitive domain are based on test results at the end of each cycle with 70 Minimum Completion Criteria (KKM). The process began with a pre-cycle which aimed to see students' initial abilities before the application of the scientific approach, then the scores collected from the pre-cycle were 10 students or $35,7 \%$ with an average score of 73 .

The learning process in the first cycle of the scientific approach began to be applied, so the results found were not too significant where there were only 14 students or $50 \%$ with a class average score of 74.6 if you saw only 4 students who showed an improvement from pre-cycle to cycle I, with these considerations the researcher continued the learning process to cycle II. In the second cycle, the completeness of the cognitive learning outcomes reached as many as 23 students or $82.1 \%$ with an average score of 77.3 these results indicated that achievement for cognitive learning outcomes was achieved in cycle II. Based on the data collected, it can be said that there was an improvement in students' cognitive learning outcomes at MTs.S Ar-Raudhatul Hasanah Sibolga. The following shows the data on improving students' learning outcomes through a scientific approach in each cycle.

Table 4. Learning outcomes in each cycle

\begin{tabular}{|c|c|c|c|}
\hline CAR Cycle & Average Score & $\begin{array}{c}\text { Number of } \\
\text { Completeness }\end{array}$ & $\begin{array}{c}\text { Percentage of Students } \\
\text { Completeness }\end{array}$ \\
\hline Pre-action & 73 & 10 & $35.7 \%$ \\
\hline Cycle I & 74.6 & 14 & $50 \%$ \\
\hline Cycle II & 82.1 & 23 & $82.1 \%$ \\
\hline
\end{tabular}

From table 4 above, it is shown that students' learning outcomes through a scientific approach to science learning in VIII grade students of MTs.S ArRaudhatul hasanah have increased in each cycle. The data above is presented in figure 2 . 


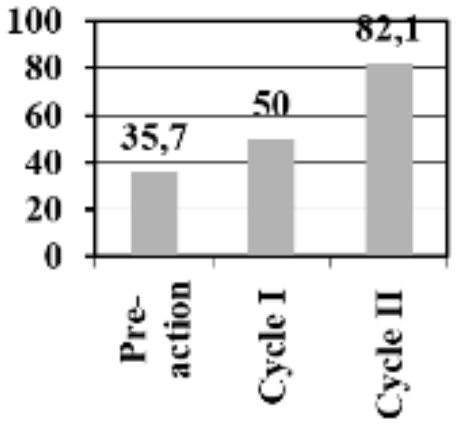

Figure 2 Pre-action, cycle I and cycle II learning outcomes diagram.

The data above is in line with Alamsyah (2017) who found that learning outcomes from the application of the scientific approach from cycle I to cycle III showed an improvement with an average score of 67 in cycle I, increasing to 77 in cycle II and to 84 in cycle III. Furthermore, individual completeness increased significantly from cycle I by $38 \%$, in cycle I to $76 \%$, and in cycle III to $92 \%$ [10]. KKM).

Each cycle ends with a reflection which aims to evaluate and study every process that has been carried out during the learning process from pre-cycle to cycle II. The application of the scientific approach to student activities has gone well and consistently in accordance with the planning formulated in the lesson plan, although in some stages it is still not maximally directed, this is due to the various conditions or character of the students. Below is a summary of the reflections for each cycle.

In the implementation of cycles, several things learning activities was carried out using a scientific approach, including: 1) The activeness of students in asking reached a good category where in the final cycle the student average score of $75 \%$ was one of the indicators which shows that the attitude of curiosity is better than before, 2) Student learning outcomes in science subjects also show a significant increase, $82.1 \%$ completeness of learning, 3) students are used to learning through a scientific approach, 4) students begin to dare to express opinions and ask the teacher, 5) students are also actively involved in discussions between groups in the learning process. Of course, behind the success obtained from each cycle there are also obstacles so that it is necessary to take alternative actions to continue to achieve success in that cycle.
Table 5. Barriers and alternatives to action for each cycle

\begin{tabular}{|l|l|l|}
\hline No & \multicolumn{1}{|c|}{ Barriers } & Alternative Actions \\
\hline 1 & $\begin{array}{l}\text { In each learning } \\
\text { cycle there are still } \\
\text { students who do } \\
\text { not care about the } \\
\text { presentation } \\
\text { process }\end{array}$ & $\begin{array}{l}\text { The teacher gives } \\
\text { directions to students } \\
\text { who are less active to } \\
\text { stay focused on } \\
\text { listening to the results of } \\
\text { the presentation and } \\
\text { preparing questions in } \\
\text { each group } \\
\text { presentation session }\end{array}$ \\
\hline $\begin{array}{l}\text { In each cycle there } \\
\text { are still students } \\
\text { who have not } \\
\text { been able to } \\
\text { achieve the KKM } \\
\text { score }\end{array}$ & $\begin{array}{l}\text { Teachers motivate and } \\
\text { guide students to be } \\
\text { more able to interpret } \\
\text { themselves when facing } \\
\text { exams so that those } \\
\text { who have not been able } \\
\text { to reach the KKM can } \\
\text { fully get the value } \\
\text { according to the KKM. }\end{array}$ \\
\hline
\end{tabular}

\section{CONCLUSION}

In the pre-cycle process, researchers have not applied a scientific approach to science learning but the percentage of curiosity reaches $14.3 \%$ or as many as 4 people and learning outcomes reach $35.7 \%$ or as many as 10 people, the data collected has not reached the desired indicators, so the action process continues towards cycle 1 . In cycle I, where the learning process has implemented actions with a scientific approach so that the achievement of students' curiosity attitudes reaches $39.3 \%$ or as many as 11 people and $50 \%$ of learning outcomes or as many as 14 people. The process at this stage still has not reached the expectations which are the objectives of the research, so the cycle continues to cycle 2

In cycle II, it was found that the increase in students' scientific attitudes was better with a percentage reaching $75 \%$ in curiosity or as many as 21 people and $82.1 \%$ in learning outcomes or as many as 23 people. The results in cycle II are categorized as good. Based on data analysis carried out from precycle, cycle I, and cycle II, it can be concluded that through science learning with the scientific approach method can increase students' curiosity attitudes and student learning outcomes of MTs.S Ar-Raudhatul Hasanah Sibolga. 


\section{REFERENCES}

[1] Department of National Eduaction, Law No. 20 Concerning The National Education System Bureau of Law and Organization of the Secretary-General of the Ministry of National Education, Jakarta, 2003.

[2] K.J. Kaufman, 21 Ways to 21st Century Skills: Why Students Need Them and Ideas for Practical Implementation, Kappa Delta Pi Record 49(2) (2013) 78-83. DOI: https://doi.org/10.1080/00228958.2013.786594

[3] C. Kivunja, Teaching Students to Learn and to Work Well with 21st Century Skills: Unpacking The Career and Life Skills Domain of The New Learning Paradigm, International Journal of High Education 4(1) (2014) 1-11.

[4] C. Ruini, G.A. Fava 2015, Clinical Applications of Well-Being Therapy, in Positive Psychology in Practice, John Wiley \& Sons Inc, 2015. DOI: https://doi.org/10.1002/9781118996874.ch28

[5] Van Hayus, H.N. Pramesthi, A.N.C. Saputro, E. Susanti, Penerapan Pendekatan Joyful Learning dengan Metode Guided Discovery Untuk Meningkatkan Rasa Ingin Tahu dan Prestasi Belajar Pada Materi Hidrokarbon Siswa Kelas X SMA Negeri 1 Ngemplak Boyolali Tahun Ajaran 2013/2014, Journal Pendidikan Kimia Universitas Sebelas Maret 4(1) (2015) 204-210.

[6] Y.K. Kartika, E. Pujiastuti, E. Soedjoko, The
Effectiveness of Project Based Learning with Creative Mind-Map Tasks for Improving Mathematical Connection Ability and Student Curiosity, Unnes Journal of Mathematics Eduation 8(2) (2019) 145-151.

[7] A. Machin, Implementasi Pendekatan Saintifik, Penanaman Karakter dan Konservasi Pada Pembelajaran Materi Pertumbuhan, Jurnal Pendidikan IPA Indonesia 3(1) (2014) 28-35. DOI: https://doi.org/10.15294/jpii.v3i1.2898

[8] A. Wijayanti, Pengembangan Autentic Assement Berbasis Proyek dengan Pendekatan Saintifik untuk Meningkatkan Keterampilan Berpikir Ilmiah Siswa, Jurnal Pendidikan IPA Indonesia 3(2) (2014) 102-108.

[9] H. Torrance, J. Pryor, Developing Formative Assessment in The Classroom: Using Action Research to Explore and Modify Theory, British Educational Research Journal 27(5) (2001) 615631.

DOI: https://doi.org/10.1080/01411920120095780

[10] B.M. Matthew, A.M. Huberman, J. Saldana, 2016, Qualitative Data Analysis A Methods Sourcebook, in Nursing standard (Royal College of Nursing (Great Britain) 3rd ed, Sage Publication, 2016.

[11] N. Alamsyah, Penerapan Pendekatan Saintifik Untuk Meningkatkan Kreativitas dan Hasil Belajar Siswa dalam Mata Pelajaran IPA, Jurnal Pendidikan Teori dan Praktik 1(1) (2017) 82. 